\title{
Ruptured yolk sacs and visceral fungi in emergent pink salmon alevins: histopathology and relation to marine survival
}

\author{
Gary D. Marty ${ }^{1,3, *}$, Ronald A. Heintz ${ }^{2}$ \\ ${ }^{1}$ Department of Anatomy, Physiology, and Cell Biology, School of Veterinary Medicine, University of California, \\ 1 Shields Ave., Davis, California 95616-8732, USA \\ ${ }^{2}$ National Marine Fisheries Service, Auke Bay Laboratory, 17109 Pt. Lena Loop Rd., Juneau, Alaska 99801-8344, USA \\ ${ }^{3}$ Present address: Animal Health Centre, Ministry of Agriculture and Lands, 1767 Angus Campbell Rd., Abbotsford, \\ British Columbia V3G 2M3, Canada
}

\begin{abstract}
Marine survival of anadromous salmon species is highly variable, and causes of this variability are often unknown. In the 1990s, cultured pink salmon Oncorhynchus gorbuscha alevins from 2 different regions in Alaska, USA, had years with increased postemergent mortality that could not be attributed to viruses, bacteria, or parasites. In both regions, lifetime marine survival of the most severely affected fish groups was as low as $1.1 \%$ in 1 region and $0.13 \%$ in the other region. To determine causes of morbidity, alevins from both regions were sampled for detailed histopathology $(\mathrm{n}=$ 144 and 36). Microscopic lesions associated with increased postemergent mortality included ruptured yolk sacs or 'coagulated yolk' (up to $38 \%$ of abnormal fish affected) and invasive fungi in the stomach or swimbladder (up to $39 \%$ of abnormal fish affected). The diagnosis of a ruptured yolk sac was based on the presence of yolk protein in the peritoneal cavity. Putative yolk proteins sometimes also distended peritoneal macrophages, systemic vessels, hepatocyte cytoplasm, splenic macrophages, and renal ducts. The most severe case of visceral fungi had hyphae invading from the stomach into the swimbladder and kidney. In the hatchery with the greatest postemergent mortality, $38 \%$ of the abnormal fish sampled had no significant microscopic lesions. We hypothesize that ruptured yolk sacs and visceral fungi occurred in fish that were predisposed to develop these lesions because of poor body condition. High prevalence of these lesions might be a useful marker for predicting poor marine survival.
\end{abstract}

KEY WORDS: Pink salmon · Oncorhynchus gorbuscha $\cdot$ Ruptured yolk sac $\cdot$ Alevins $\cdot$ Histopathology Marine survival

\section{INTRODUCTION}

Pink salmon Oncorhynchus gorbuscha offer many advantages for use in salmon ranching and as markers of environmental health. Throughout the North Pacific, $>1.2$ billion pink salmon fry are cultured and released annually from the United States, Russia, and Japan (North Pacific Anadromous Fish Commission [NPAFC] Statistical Yearbook: www. npafc.org). Pink salmon are the smallest of the Pacific salmon species, and they have a consistent 2 yr life cycle. In south-central and southeastern Alaska, USA, pink salmon spawn in coastal streams during late summer, often in intertidal regions (Helle et al. 1964, Heard 1991). Eggs develop and hatch in gravel substrate, where embryonic and larval development continues through the winter. As yolk stores become depleted in early spring, alevins emerge from the gravel and migrate immediately to the ocean (Heard 1991). After feeding in the open ocean for about $1.5 \mathrm{yr}$, they return to their natal streams where they spawn and die. 
Marine survival among pink salmon populations is highly variable over time. Growth and survival during the first few weeks in the ocean are considered the most important determinants of the size of subsequent adult returns (Parker 1968). Variability of pink salmon returns has been attributed to changes in climate (Downton \& Miller 1998, Morita et al. 2006), genetic variability (Geiger et al. 1997), coded wire tagging or fin clipping (Wertheimer et al. 2002), exposure to weathered crude oil during early development (Bue et al. 1996, Heintz et al. 2000), and differences in food availability and size of alevins (Cooney \& Brodeur 1998). Recent papers have correlated infestations of parasitic copepods (sea lice) with pink salmon population decline (Krkosek et al. 2006, 2007); however, Pacific strains of parasitic copepods (Yazawa et al. 2008) cause minimal or no mortality with environmentally relevant infestations under controlled laboratory conditions (Jones et al. 2007, 2008, Webster et al. 2007).

Pink salmon aquaculture includes spawning and rearing of eggs and alevins; fry are released into the ocean soon after they absorb their yolk, and returning adults are harvested from the ocean. In Alaska, pink salmon hatcheries are located near the intertidal region of the mouth of a stream. Unlike some other salmon species, cultured pink salmon are reared in artificial substrate and are not fed before they emerge from the substrate. Emergent alevins are sometimes held in saltwater pens and fed formulated diets until zooplankton concentrations in nearby waters can better support their growth. Mortality during this holding phase, which lasts from 0 to $21 \mathrm{~d}$, is usually $<0.5 \%$.

Over the past $20 \mathrm{yr}$ of pink salmon culture in Alaska, mortality of emergent alevins in some years was significantly greater than in other years, and high mortality before release was sometimes associated with poor marine survival. In April 1994, mortality of emergent pink salmon reared by the Prince William Sound Aquaculture Corporation in south-central Alaska was as high as $17 \%$ in one hatchery, but near normal in another hatchery. Routine examination for parasites, bacteria, and viruses yielded no evidence to explain the cause of increased mortality. Therefore, detailed histopathology was done to determine if developmental abnormalities, lesions, or other pathogens were contributing to increased mortality. In April 1999, mortality of emergent pink salmon reared by the US National Marine Fisheries Service at their Little Port Walter research facility in southeastern Alaska was also greater than normal. These alevins were part of a multigenerational study of the effects of sublethal crude oil exposure during early development on ocean survival and reproductive success; detailed histopathology of emergent alevins was part of the study design. In 1994 and 1999, groups with high mortality had a high prevalence of ruptured yolk sacs independent of any experimental treatment, and some abnormal alevins in 1994 also had invasive visceral fungi. Ruptured yolk sacs have long been described in several other salmonid species as 'coagulated yolk' or 'white spot disease' (Leach 1924, Agersborg 1933, Fish \& Burrows 1939, Mazuranich \& Nielson 1959). Although coagulated yolk and white spot disease have been well recognized since at least the late 1800s (Leach 1924), histopathology of the condition has never been reported. Among the affected pink salmon in our study, adult returns in both regions were among the lowest in the 1990s. The objectives for the present study were to (1) describe the microscopic features of ruptured yolk sacs and visceral fungal infections in emergent pink salmon alevins; and (2) present hypotheses on potential causes of these lesions and their relation to postemergent mortality and subsequent adult returns.

\section{MATERIALS AND METHODS}

1994 emergent alevins, Prince William Sound. Alevins from 3 production hatcheries were sampled for histopathology on 13 April 1994, within 24 h of volitional emergence from the substrate (Table 1) and before they were fed. Postemergent mortality at the 3 hatcheries was different, classified generally by hatchery managers as relatively low, mid-level, or high. At the hatcheries with mid-level and high mortality, hatchery personnel stratified the alevins into normal and abnormal groups based on the clinical signs

Table 1. Oncorhynchus gorbuscha. Clinical history of pink salmon alevins sampled for histopathology from sites in Prince William Sound, Alaska, USA, in 1994 (= 1993 brood year). Alevins were sampled as they emerged from substrate at Cannery Creek hatchery $(\mathrm{CCH})$, Armin F. Koernig hatchery (AFK), and Wally Noerenberg hatchery (WNH), and before they emerged from the gravel in a natural stream that flows into Ewan Bay

\begin{tabular}{|lcccc|}
\hline Sample site & $\begin{array}{c}\text { Postemergent } \\
\text { mortality }\end{array}$ & $\begin{array}{c}\text { Sample } \\
\text { date }\end{array}$ & $\begin{array}{c}\text { Relative } \\
\text { behavior }\end{array}$ & $\begin{array}{c}\text { No. } \\
\text { examined }\end{array}$ \\
\hline Ewan Bay & Unknown & 24 April & Not examined & 24 \\
WNH & Low $(1.9 \%)$ & 13 April & Normal & 24 \\
CCH & Mid-level (5.5\%) & 13 April & Normal & 24 \\
& & & Abnormal & 24 \\
AFK & High (17\%) & 13 April & Normal & 24 \\
\multicolumn{2}{|l}{ abnormal } & 24 \\
\hline
\end{tabular}


they observed. Normal fish emerged from their freshwater incubation substrate and swam several meters downstream through a trough of flowing water (positive rheotaxis) that emptied into marine net pens; during this transition, normal fish rarely stopped swimming. In obvious contrast, abnormal fish regularly stopped swimming and settled to the bottom of the trough; when they did move, they often swan erratically (whirling and spinning). Many abnormal fish died in the troughs or immediately after arrival in the net pens, but only living fish were sampled for histopathology. To compare the hatchery-reared fish to wild fish, alevins were sampled on 24 April 1994 from the stream discharging into Ewan Bay. This stream was the historic source for broodstock used in 2 of the 3 hatcheries; the wild alevins were sampled before they emerged from the gravel, and their behavior was not observed. All alevins were examined for gross abnormalities, killed with an overdose of anesthetic (Finquel $\left.{ }^{\circledR}\right)$, weighed, measured (total length), and fixed whole in $10 \%$ neutral buffered formalin.

Each fish was coded for blind study and processed into paraffin. Before embedment, each alevin was sectioned transversely just caudal to the anus, and the cut face of the postanal part was embedded so that transverse sections were cut through the caudal peduncle; the rest of the fish (body and head) was embedded in lateral recumbency. At least 6 step sections (each 4 to $5 \mu \mathrm{m}$ thick) were cut from each alevin, sections were stained routinely with hematoxylin and eosin, and semiquantitative histopathology was conducted as previously described (Marty et al. 1997a). Microscopic changes were scored as none (0), mild (1), moderate (2), or severe/abundant (3). Prevalence was calculated as the number affected (scores of 1,2 , or 3 ) divided by the number examined.

Cohorts of emergent hatchery alevins were marked with coded wire tags and adipose fin clips to estimate numbers of returning adults (in 1995). This was part of routine hatchery operations and management by the Alaska Department of Fish and Game.

1999 emergent alevins, Little Port Walter. The fish included in this study were part of a larger laboratory study examining the effects of continuous crude oil exposure on development and on expression of cytochrome P4501A in pink salmon alevins. Here, we focus on ruptured yolk sacs in the emergent alevins, and the relation of ruptured yolk sacs to subsequent adult returns. Fish used in the present study were progeny of 303 females and 66 male wild pink salmon captured on 14 September 1998, from a stream (Lover's Cove Creek) in Port Walter, Alaska, located about $7 \mathrm{~km}$ from the Little Port Walter hatchery. Gametes were pooled, divided into 30 aliquots (10 each in incubators with low oil concentration, high oil concentration, and controls), and each aliquot was incubated in a separate gravel incubator at the Little Port Walter hatchery as previously described (Marty et al. 1997a). Near the time of peak emergence, 36 fish (12 control and 24 exposed) were randomly sampled from incubators for histopathology within $24 \mathrm{~h}$ of emergence from their gravel substrate and before feeding. Methods for semiquantitative histopathology were the same as for fish sampled from Prince William Sound in 1994.

Cohorts of the sampled fish were marked before release so that survival could be estimated when fish returned as adults in 2000. Control fry were marked within $24 \mathrm{~h}$ of emergence from their substrate by excising the adipose and right pelvic fins. The fish were placed in holding nets suspended in the top $2 \mathrm{~m}$ of the estuary immediately after marking. Two release strategies were employed. Between 23 March and 18 April 1999, the marked fish were held for $24 \mathrm{~h}$ and then released ( $n=36515)$. Any mortalities in the holding pens were subtracted from the count of marked fish placed in the net; these averaged $0.60 \pm 0.16 \%$ (mean \pm SEM). After 18 April, emerging fish were marked, placed in holding nets, and released on the same day, 6 May 1999 ( $\mathrm{n}=29$ 876); this mass release was consistent with a notable increase in the number of wild fish emigrating from a nearby stream (Sashin Creek). Mortality in the group held from emergence to the 6 May release averaged $4.61 \pm 0.77 \%$. Fish returned as adults in the fall of 2000 to Sashin Creek. Returning adults were trapped in a weir and inspected for fin clips. The total number of fish with missing adipose and right pelvic fins was recorded and survival estimated as the number of adult returns divided by the number of fry released. Similar procedures were employed for fish from the oil exposure groups. Fin clips that identified those groups included the adipose and left pelvic fin (low dose exposure) or the adipose only (high dose exposure). Fish that returned to adjacent streams or were captured in commercial fisheries were not included among the returns. Although this might miss some straying fish, the stray rate of the 1995 brood year hatched at Little Port Walter was $<5 \%$ (Wertheimer et al. 2000). Returns from experimental studies were compared to commercial harvest of adult pink salmon reported by the Alaska Department of Fish and Game, Commercial Fisheries Division, for southeast Alaska.

Statistical analysis. Semiquantitative lesion scores from the 1994 Prince William Sound study were analyzed with principal components analysis followed by analysis of variance (ANOVA) or multivariate analysis of variance (MANOVA) of the first 4 scale values derived from principal components analysis (Marty et al. 1997b). The primary goal was to detect overall differences among all fish, all relatively normal fish, and 
between relatively abnormal and normal fish at each hatchery with increased mortality. Sample differences were determined on scale values using Tukey's HSD method. ANOVA was not done on scores for individual lesions because scored data were usually not normally distributed, and the probability of Type I error increases with multiple comparisons. Differences among alevin length and weight were compared using ANOVA, followed by multiple $t$-tests to detect differences between group means. For the fish from Little Port Walter, a chi-squared $2 \times 2$ contingency table followed by Fisher's exact probability test was used for 2 comparisons: (1) the frequency of ruptured yolk sacs in control fish versus oil-exposed fish in 1999 (the present study); and (2) the frequency of ruptured yolk sacs among all fish in 1999 versus fish cultured under similar conditions and sampled for histopathology near the time of emergence at the Little Port Walter Facility in $1993(\mathrm{n}=143$, Marty et al. 1997a) and $2000(\mathrm{n}=160$, Carls et al. 2005).

\section{RESULTS}

\section{Histopathology of normal and ruptured yolk sacs}

Normal maturation from alevins to fry involves depletion of yolk proteins as a key process. Intact yolk sacs in emergent fish are pale, basophilic, and contain yolk protein that is homogeneous and stains intensely eosinophilic (Fig. 1A). The volume of yolk protein in emergent fish varies from none to abundant. As the volume of yolk protein decreases, the surrounding yolk sac contracts and thickens. After the yolk protein is completely depleted, the yolk sac is gradually resorbed and small volumes of yolk sac remain in some fish at least $3 \mathrm{wk}$ after the yolk protein is completely depleted (Marty et al. 1997a). Small volumes of peritoneal fluid surrounding the normal yolk sac do not usually contain enough protein to stain with hematoxylin and eosin.

Many of the fish in the present study had abnormal yolk sacs, probably a result of yolk sac rupture at some time during development. In some affected fish, yolk sacs were thin with irregular margins (Fig. 1B); the contracted yolk sac and surrounding peritoneal cavity contained homogeneous pale-staining protein that tended to be more intensely eosinophilic than normal plasma proteins (Fig. 1B). In other fish, partial rupture of the yolk sac was characterized by remnants of intensely eosinophilic yolk protein within the contracted yolk sac, while putative yolk proteins in the peritoneal cavity and systemic vessels stained less intensely (Fig. 1C). In one severely affected fish sampled in 1999, putative yolk proteins distended the intestinal lamina propria, ruptured through the overlying epithe- lium, and partly filled the intestinal lumen (Fig. 1C,D). Columnar absorptive cells in the distal intestine of this fish had brightly eosinophilic material distending the apical cytoplasm.

In most affected fish, yolk proteins remained in the peritoneal cavity, but putative yolk proteins were sometimes common in vessels and phagocytic cells throughout the body, especially in the kidney (Figs. 1B \& 2A). Renal tubular epithelial cell cytoplasm sometimes contained large protein droplets Fig. 2B), and protein deposits sometimes distended tubules and large excretory ducts. In the liver, hepatocyte cytoplasm was distended by intensely eosinophilic protein droplets (Fig. 2C), and macrophages distended with yolk protein were common in the peritoneal cavity, spleen, and peripheral vasculature. Other changes that occur in fish with ruptured yolk sacs included dilated urinary spaces filled with pale protein (Fig. 2A), and eosinophilic hyaline cartilage (Fig. 1B,C).

\section{Histopathology of visceral fungal infections}

In addition to ruptured yolk sacs, 6 emergent fish sampled in 1994 had invasive fungi that were most common in the stomach (Fig. 3). The hyphae were nonpigmented, 3 to $10 \mu \mathrm{m}$ in diameter, nonseptate, with occasional acute branches; cell wall margins were not parallel. The fungi did not have well-defined spores or conidia. Tissue reaction included hyperplasia of the invaded mucosa, and necrosis of invaded smooth muscle layers (e.g. focal karyorrhexis and karyolysis, Fig. 3B); invasive hyphae were not associated with inflammatory cells. By the time the fungal infection was diagnosed by histopathology, affected fish had either died or been released; therefore, fungal culture was not carried out. However, morphological features are consistent with descriptions of Phoma herbarum (Ross et al. 1975). All but 2 affected fish had fungi in the gastric lumen, and in more severe cases, the fungi invaded the gastric wall. In the most severe case, fungi extended from the swimbladder lumen though the wall to invade ventrally into the wall of the stomach and intestine, and dorsally into the kidney. The swimbladder epithelium in this fish was hyperplastic, and fungal hyphae invaded vessels, resulting in hemorrhage that distended the swimbladder wall (see Figs. S1 \& S2, available as supplementary material at www.int-res. com/articles/suppl/d088p115_app.pdf). The swimbladder lumen in this fish also contained colonies of bacterial rods and scattered refractile foreign material, presumably aspirated through the pneumatic duct. In another fish, the swimbladder was filled with abundant bacteria and small numbers of fungal hyphae, but hyphae did not extend into surrounding structures. 


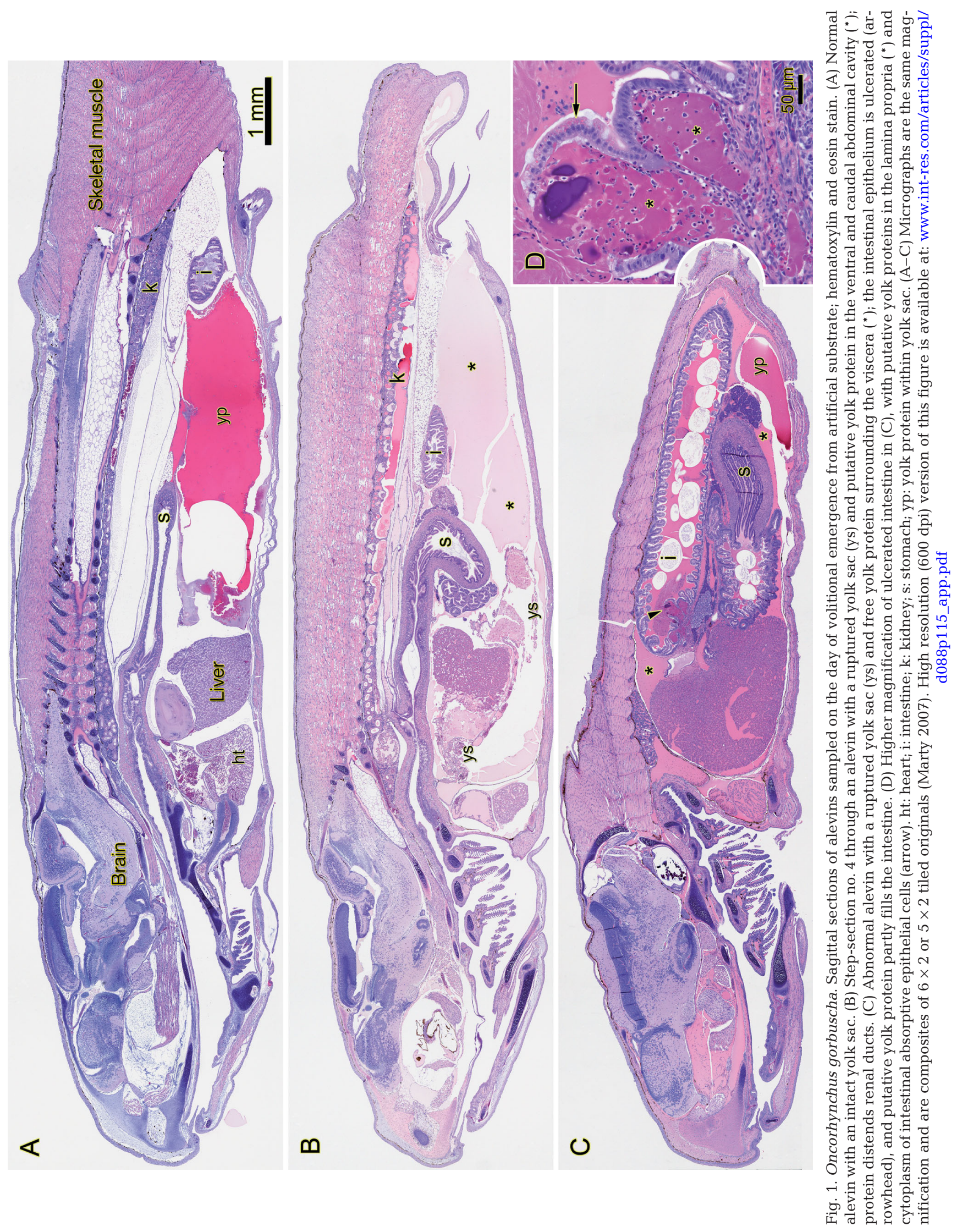




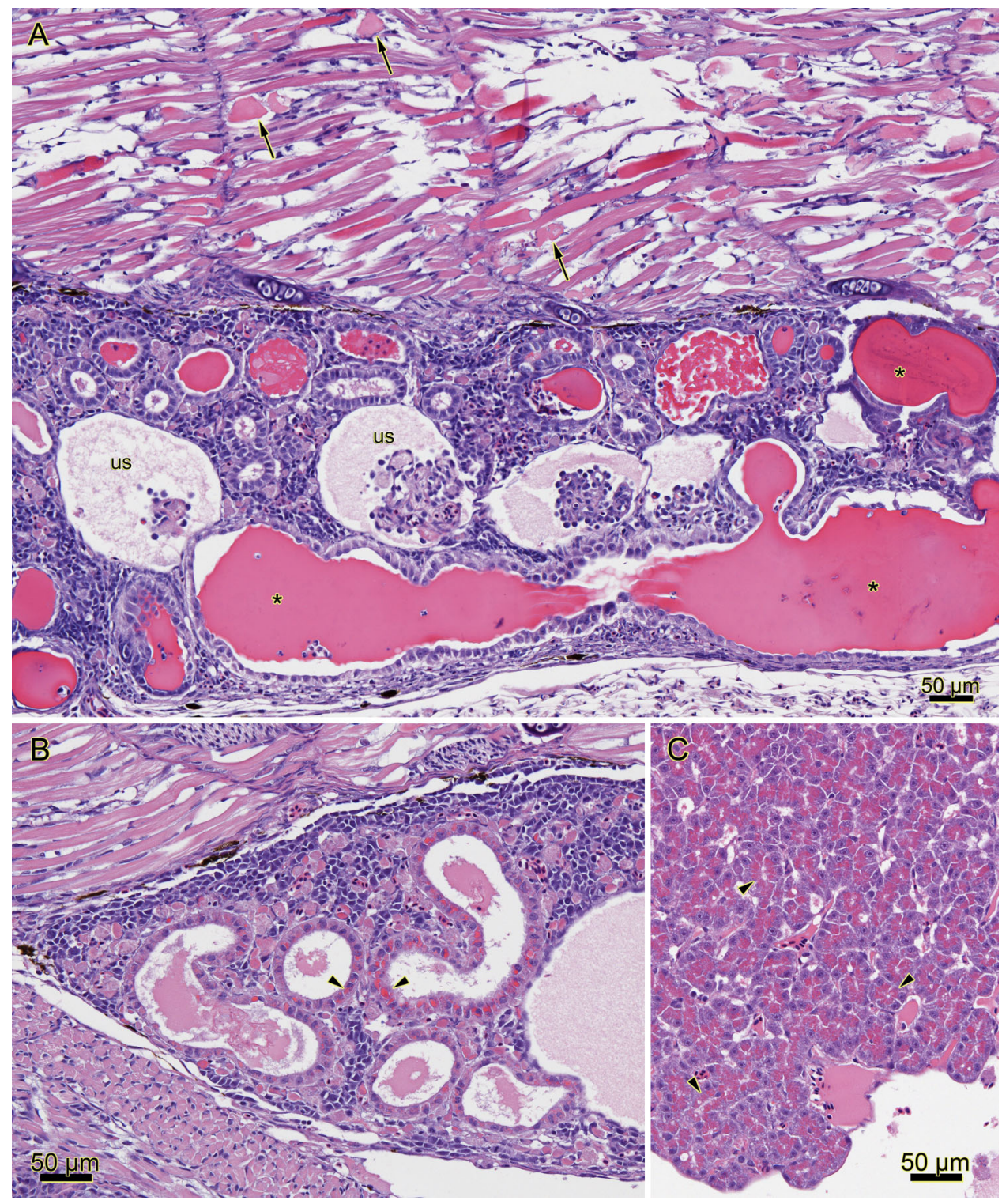

Fig. 2. Oncorhynchus gorbuscha; hematoxylin and eosin stain. (A) Step-section no. 3 from the fish in Fig. 1B. The archinephric duct and several renal tubules are distended by homogenous eosinophilic material $\left({ }^{*}\right)$, probably derived from yolk proteins. Urinary spaces (us) are distended by pale eosinophilic material, and some skeletal myofibers are necrotic (arrows). (B) Step-section no. 6 from the fish in Fig. 1B. Tubular epithelial cells in the anterior kidney contain brightly eosinophilic cytoplasmic protein droplets (arrowheads), and many interstitial cells contain dull eosinophilic protein. (C) Step-section no. 6 from the fish in Fig. 1B. Hepatocyte cytoplasm contains abundant brightly eosinophilic droplets of putative yolk proteins (arrowheads). High resolution (600 dpi) version of this figure is available at: www.int-res.com/articles/suppl/d088p115_app.pdf

\section{4 emergent alevins, Prince William Sound}

Among the 6 sample groups, some lesions were most frequent and severe among relatively abnormal fish at the hatchery with high mortality (Fig. 4). Thirty-eight percent of these fish had a ruptured yolk sac and $25 \%$ had fungi in the stomach or swimbladder, but none of the fish with gastric fungi had a ruptured yolk sac. Six of the 24 abnormal fish had degeneration and necrosis of skeletal muscle fibers (Fig. 2A); 4 of these fish also had a ruptured yolk sac, and the swimbladder in 1 of these fish contained abundant bacteria with a few fungal hyphae. Scores for peritoneal macrophages tended to be greatest in fish from this hatchery, but peritoneal macrophages occurred in all hatchery groups (Fig. 4).

Differences in clinical signs among emergent alevins were associated with differences in microscopic lesions. Visceral fungi and skeletal muscle necrosis 


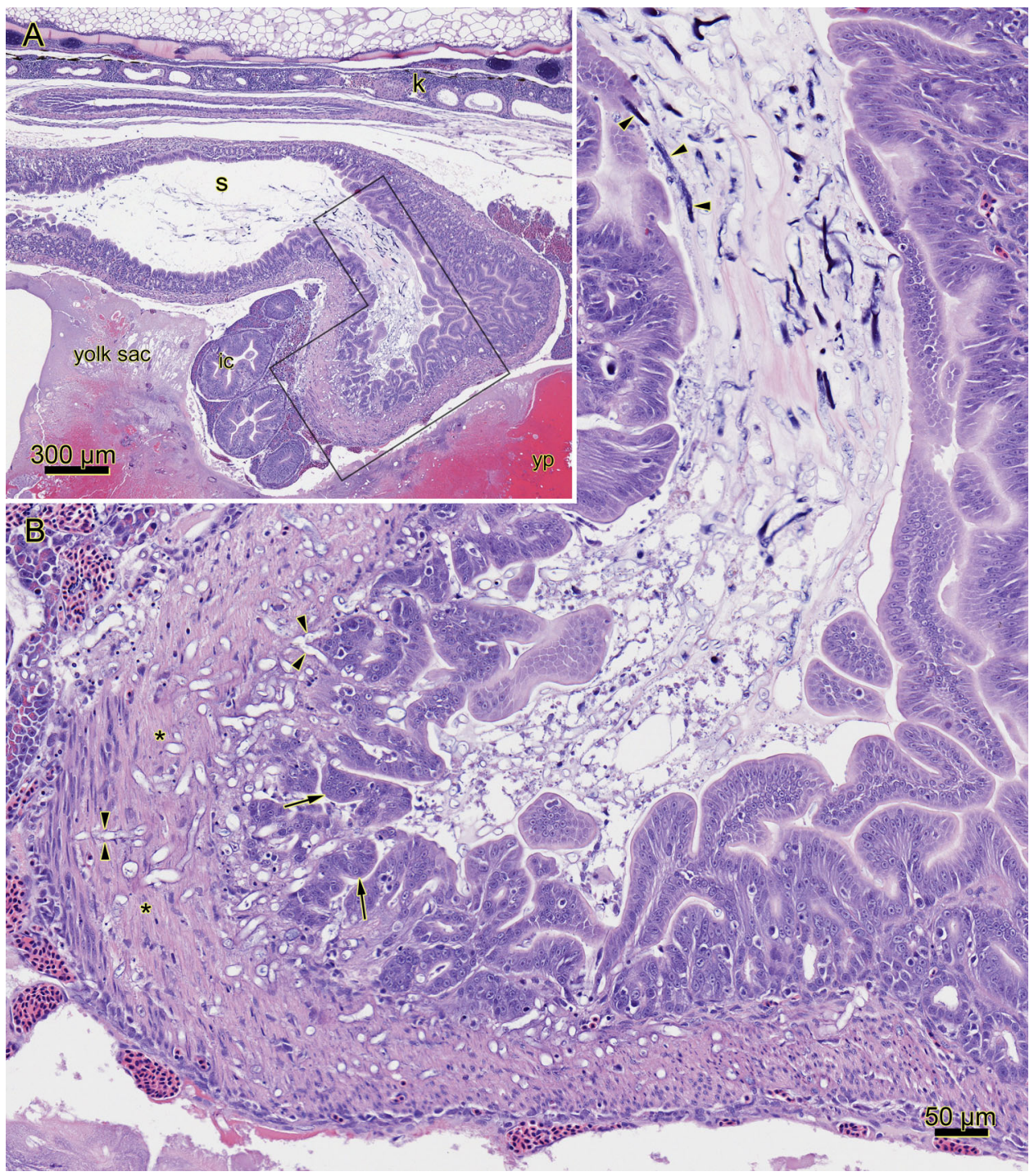

Fig. 3. Oncorhynchus gorbuscha; hematoxylin and eosin stain. (A) Overview of stomach (s) and surrounding structures: trunk kidney (k), intestinal ceca (ic), and yolk protein (yp) within yolk sac; box outlines area shown at greater magnification in (B). (B) Fungal hyphae in lumen stain deeply basophilic, whereas hyphae in the gastric wall stain poorly (arrowheads). Invasive hyphae are associated with hyperplastic gastric epithelium (arrows) and smooth muscle cells with karyorrhexis and karyolysis

${ }^{*}$ ). High resolution (600 dpi) version of this figure is available at: www.int-res.com/articles/suppl/d088p115_app.pdf

occurred only in abnormal alevins, whereas ruptured yolk sacs occurred in normal and abnormal alevins. Note, however, that the 2 cases of ruptured yolk sacs in normal alevins from the hatcheries with low and mid-level mortality were very mild; they did not have the systemic yolk proteins characteristic of severe cases shown in Fig. 1. Of 24 abnormal alevins from the hatchery with the greatest mortality, 15 (63\%) had visceral fungal infection, skeletal muscle necrosis, or a ruptured yolk sac, and these lesions seemed sufficient to explain abnormal clinical signs in all but 1 of the affected alevins (1 of the fish had only mild skeletal muscle necrosis). The cause of morbidity in the other
9 of 24 alevins could not be determined from microscopic examination.

Fish groups with abnormal clinical signs also had a premature decrease in hepatocellular glycogen stores. At the hatchery with low mortality, normal development included abundant hepatocellular glycogen and depleted yolk stores (Fig. 5). By comparison, in abnormal alevins from the hatchery with high mortality, glycogen stores were depleted despite relatively abundant yolk (Fig. 5). Also at this hatchery, scores for glycogen stores were less in abnormal alevins with ruptured yolk sacs (mean score $=1.6$ ) than in abnormal alevins with intact yolk sacs (mean score $=2.5$ ). Among the ab- 

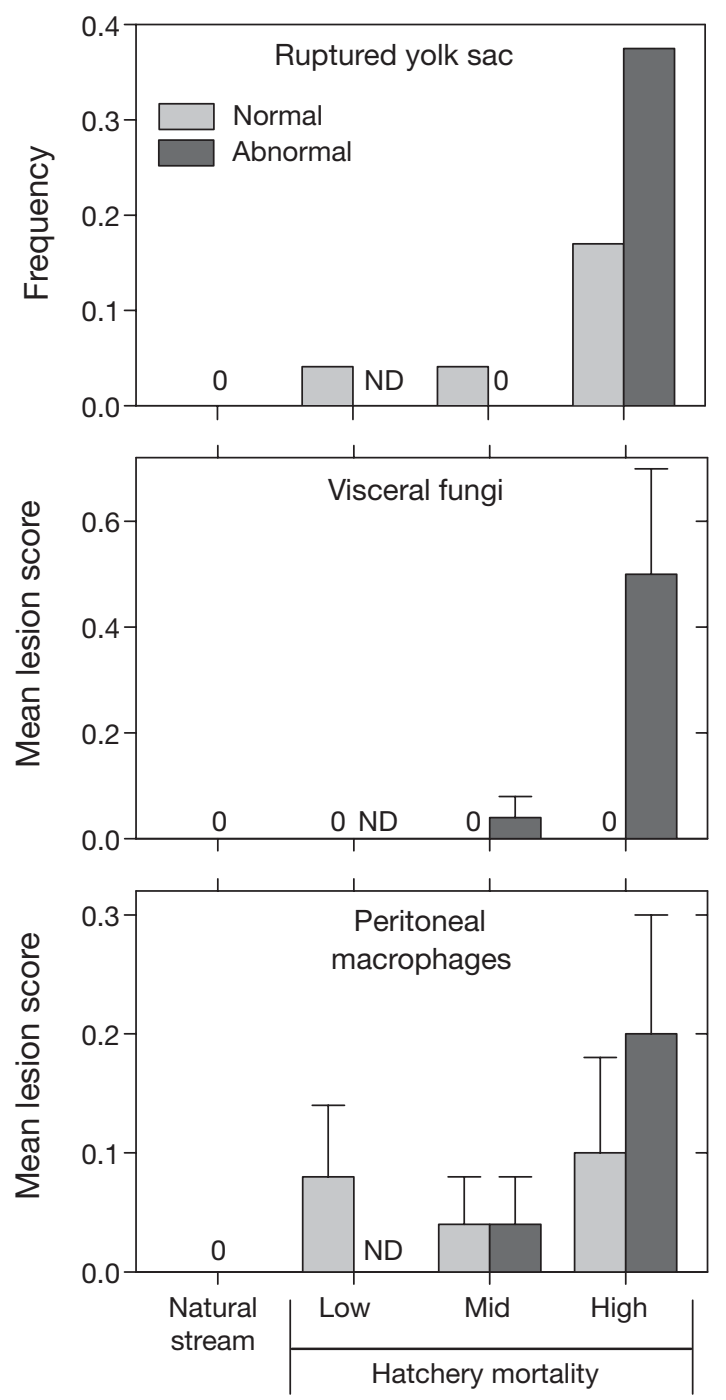

Fig. 4. Oncorhynchus gorbuscha. Frequency and mean (+SE) severity scores for microscopic lesions in alevins sampled from Ewan Bay (natural stream, pre-emergent) and relatively abnormal and normal alevins sampled from hatcheries (postemergent) that had low, mid-level, or high mortality between emergence and release. ND: no data

normal alevins with ruptured yolk sacs, 6 of 9 (67\%) had yolk proteins within hepatocyte cytoplasm. Differences in other developmental changes did not seem to relate to morbidity, and details are not reported.

Statistical analysis of scored variables identified several significant differences: among the 4 sites, among normal alevins from the different sites, and between abnormal and normal alevins from the hatchery with high mortality (principal components analysis, ANOVA, p < 0.02). However, differences between abnormal and normal alevins from the hatchery with mid-level mortality were not significant. Among the
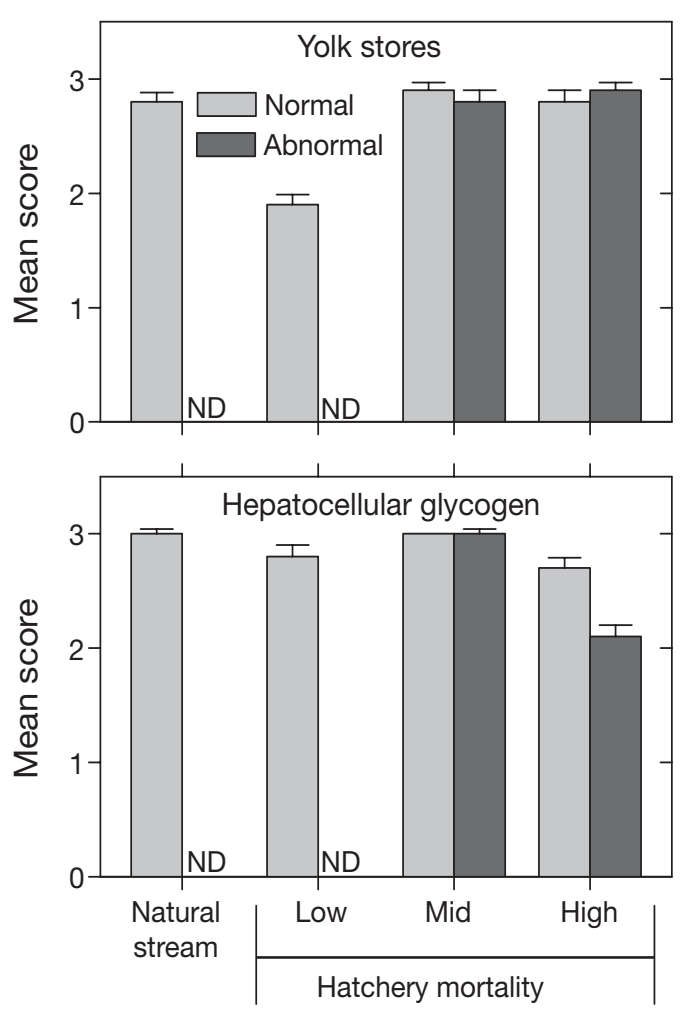

Fig. 5. Oncorhynchus gorbuscha. Mean (+SE) scores for relative amounts of yolk and hepatic glycogen in relatively abnormal and normal alevins sampled from Ewan Bay (natural stream, pre-emergent) and from hatcheries (postemergent) that had low, mid-level, or high mortality between emergence and release. ND: no data

scored variables, hepatic glycogen, ruptured yolk sacs, and skeletal muscle degeneration and necrosis contributed most to variability in the first principal component, which accounted for $15 \%$ of total variability.

All samples of hatchery-reared alevins were significantly smaller than the pre-emergent alevins captured from the ancestral stream (Fig. 6). Alevins from the hatchery with low mortality were significantly longer than alevins from hatcheries with mid-level and high mortality, but weights were not significantly different. From the hatchery with mid-level mortality, normal alevins were significantly longer than abnormal alevins (Fig. 6).

Increased mortality of pink salmon alevins in 1994 from emergence to release seemed to be associated with (1) small size of parents at all 3 hatcheries (Table 2), and (2) poor adult returns in 2 of the 3 hatcheries (Table 2). The 1993 brood was derived from parents whose weight was among the lowest of returning pink salmon during the 1990s. Adult returns were poor for pink salmon released in 1994 from the hatcheries with low and high postemergent mortality (Table 2). 

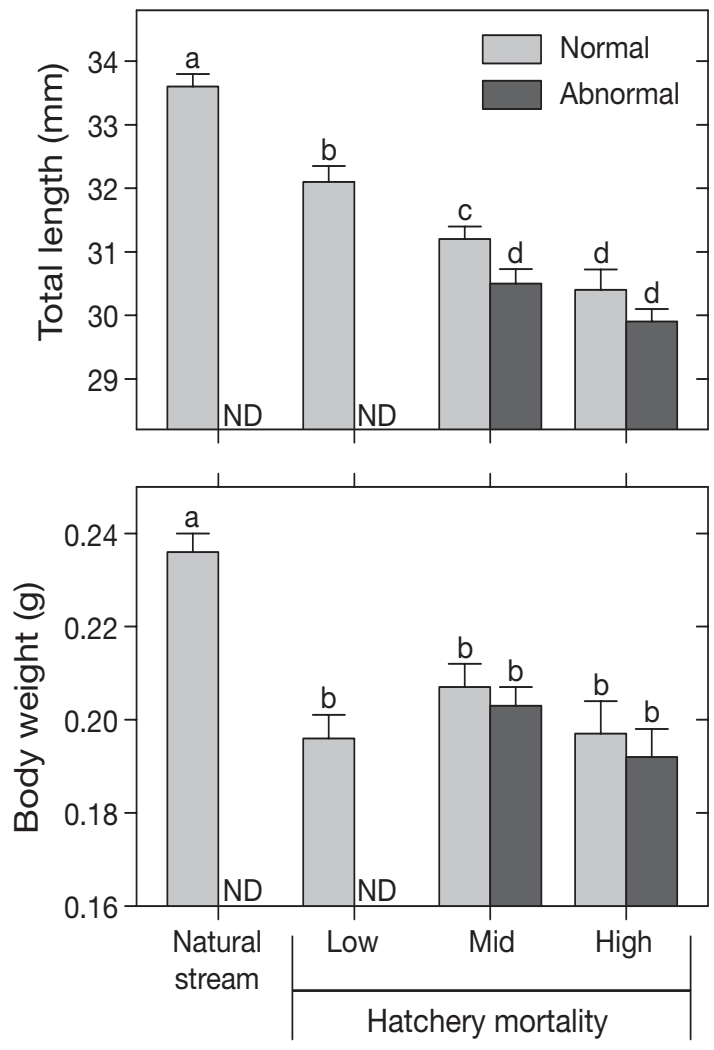

Fig. 6. Oncorhynchus gorbuscha. Mean (+SE) length and weight of alevins sampled from Ewan Bay (natural stream, pre-emergent) and relatively abnormal and normal alevins sampled from hatcheries (postemergent) that had low, midlevel, or high mortality between emergence and release. Bars with the same letter are not significantly different (multiple $t$-tests, $\mathrm{p}<0.05)$. ND: no data
By comparison, adult returns were relatively good for fish from the hatchery that had mid-level mortality in 1994.

\section{9 emergent alevins, Little Port Walter}

Ruptured yolk sacs were common in this group of fish, and prevalence in control fish (4 of 12) was not significantly different from the prevalence among oil exposure groups (10 of $24, \mathrm{p}=0.72)$; therefore, control and oiled groups were combined for reporting (Table 3). Microscopic features of ruptured yolk sacs were similar to alevins sampled in 1994 from Prince William Sound, but none of the fish from Little Port Walter had visceral fungi or skeletal muscle necrosis.

Adult returns of these fish to the Little Port Walter facility in 2000 were no more than one-tenth of the returns of the 2 other brood years studied (Table 3). Among pink salmon commercial fisheries in southeast Alaska, the number of fish harvested in 2000 was less than half of the parent generation (in 1998) and total harvest was less than any other year in the previous decade (Table 3). However, unlike the Prince William Sound fish, ruptured yolk sacs were not associated with low parent weight. Pink salmon adults in southeastern Alaska in 1998 were among the heaviest of the decade (1.6 kg, Table 3). Ruptured yolk sacs did not occur in emergent alevins examined from the Little Port Walter hatchery from brood years 1992 or 1999, when brood weight was the lowest of the decade (1.3 kg, Table 3). The proportion of fish with ruptured yolk sacs in 1999 (the present study) was significantly greater than in $1993(\mathrm{p}<0.001)$ and $2000(\mathrm{p}<0.001)$.

Table 2. Oncorhynchus gorbuscha. Mean body weight of parents, postemergent mortality $(M)$, and marine survival $(S)$ of pink salmon incubated and released from hatcheries in Prince William Sound, Alaska, USA

\begin{tabular}{|c|c|c|c|c|c|c|c|c|c|}
\hline \multirow{2}{*}{$\begin{array}{l}\text { Brood } \\
\text { year }\end{array}$} & \multicolumn{3}{|c|}{ Wally Noerenberg hatchery } & \multicolumn{3}{|c|}{ Cannery Creek hatchery } & \multicolumn{3}{|c|}{ Armin F. Koernig hatchery } \\
\hline & $\begin{array}{l}\text { Parent } \\
\text { weight } \\
(\mathrm{kg})\end{array}$ & $\begin{array}{c}\text { Emergence } \\
\text { to release } \\
M(\%)\end{array}$ & $\begin{array}{c}\text { Release } \\
\text { to return } \\
S(\%)\end{array}$ & $\begin{array}{c}\text { Parent } \\
\text { weight } \\
(\mathrm{kg})\end{array}$ & $\begin{array}{c}\text { Emergence } \\
\text { to release } \\
M(\%)\end{array}$ & $\begin{array}{c}\text { Release } \\
\text { to return } \\
S(\%)\end{array}$ & $\begin{array}{c}\text { Parent } \\
\text { weight } \\
(\mathrm{kg})\end{array}$ & $\begin{array}{c}\text { Emergence } \\
\text { to release } \\
M(\%)\end{array}$ & $\begin{array}{c}\text { Release } \\
\text { to return } \\
S(\%)\end{array}$ \\
\hline 1990 & 1.4 & 0.5 & 1.0 & 1.4 & 0.2 & 1.2 & 1.4 & 0.5 & 2.1 \\
\hline 1991 & 1.1 & 0.1 & 0.9 & 1.1 & 3.9 & 0.6 & 1.1 & 0.5 & 1.4 \\
\hline 1992 & 1.7 & 0.1 & 3.5 & 1.6 & 0.6 & 6.8 & 1.5 & 0.5 & 1.6 \\
\hline $1993^{a}$ & 1.5 & 1.9 & 1.5 & 1.3 & 5.5 & 6.2 & 1.3 & 17.1 & 1.1 \\
\hline 1994 & 1.5 & 1.3 & 3.2 & 1.4 & 2.5 & 5.1 & 1.4 & 3.5 & 1.6 \\
\hline 1995 & 1.6 & 2.9 & 3.7 & 1.5 & 1.0 & 4.3 & 1.6 & 7.2 & 6.4 \\
\hline 1996 & 1.6 & 1.3 & 8.0 & 1.6 & 0.6 & 5.4 & 1.6 & 0.5 & 13.8 \\
\hline 1997 & 1.7 & 1.0 & 9.1 & 1.6 & 1.1 & 5.9 & 1.6 & 4.5 & 8.3 \\
\hline 1998 & 1.6 & 0.2 & 6.8 & 1.6 & 6.3 & 5.0 & 1.6 & 8.8 & 5.2 \\
\hline 1999 & 1.4 & 4.9 & 6.2 & 1.4 & 1.2 & 1.6 & 1.3 & 0.5 & 3.4 \\
\hline 2000 & 1.7 & 0.03 & 4.4 & 1.6 & 0.5 & 1.1 & 1.6 & 0.2 & 5.2 \\
\hline
\end{tabular}


Table 3. Oncorhynchus gorbuscha. Histopathology and marine survival of pink salmon incubated and released from the Little Port Walter research facility in southeastern Alaska, USA. Commercial pink salmon harvest (1000s) and mean weight for each year among all commercial fisheries in the Southeast region (source: Alaska Department of Fish and Game). ND: no data

\begin{tabular}{|c|c|c|c|c|c|c|c|}
\hline \multirow[t]{2}{*}{$\begin{array}{l}\text { Brood } \\
\text { year }(t)\end{array}$} & \multirow{2}{*}{$\begin{array}{c}\text { No. alevins } \\
\text { released } \\
(t+1)\end{array}$} & \multirow{2}{*}{$\begin{array}{l}\text { No. adults } \\
\text { returned } \\
\quad(t+2)\end{array}$} & \multirow[t]{2}{*}{$\begin{array}{l}\text { Survival } \\
(\% \pm \mathrm{SE})\end{array}$} & \multicolumn{2}{|c|}{$\begin{array}{l}\text { Ruptured yolk sacs } \\
\text { (histopathology) }\end{array}$} & \multicolumn{2}{|c|}{$\begin{array}{l}\text { Southeast Alaska } \\
\text { commercial harvest }(t+2)\end{array}$} \\
\hline & & & & No. examined & Prev. (\%) & No. & Mean wt. (kg) \\
\hline 1990 & & & & & & 57299 & 1.3 \\
\hline 1991 & & & & & & 34963 & 1.5 \\
\hline $1992^{\mathrm{a}}$ & ND & ND & ND & 143 & 0.0 & 57650 & 1.4 \\
\hline $1993^{b}$ & 5454 & 114 & $2.1 \pm 0.2$ & 0 & ND & 47960 & 1.4 \\
\hline 1994 & & & & & & 64660 & 1.4 \\
\hline $1995^{\mathrm{b}}$ & 65409 & 851 & $1.3 \pm 0.3$ & 0 & ND & 28980 & 1.7 \\
\hline 1996 & & & & & & 42530 & 1.6 \\
\hline 1997 & & & & & & 77770 & 1.3 \\
\hline $1998^{c}$ & 66391 & 85 & 0.13 & 36 & 39 & 20250 & 1.5 \\
\hline $1999^{d}$ & ND & ND & ND & 160 & 0.0 & 67050 & 1.5 \\
\hline \multicolumn{8}{|c|}{$\begin{array}{l}{ }^{a} \text { Marty et al. }(1997 a) \\
{ }^{b} \text { Heintz et al. }(2000) \text {, control fish only } \\
\text { cThe present study, returns are for control fish only; ruptured yolk sac prevalence is for control and oiled fish combined } \\
\text { SE of survival estimate could not be determined } \\
{ }^{d} \text { Carls et al. (2005) }\end{array}$} \\
\hline
\end{tabular}

\section{DISCUSSION}

Ruptured yolk sacs and visceral fungi in emergent pink salmon alevins are potential markers of decreased marine survival. These lesions probably impair marine survival by increasing fish susceptibility to predation. This could occur because of decreased growth or abnormal behavior. Small fish are generally more susceptible to predation than large fish (Cooney \& Brodeur 1998), and decreased growth resulting from poor yolk utilization would result in affected fish remaining susceptible to predation longer than fish in which the yolk sac remained intact. In fish with ruptured yolk sacs, yolk proteins were scavenged by peritoneal macrophages, hepatocytes, and other cell types, but this process is probably less efficient than normal absorption through the yolk sac. Yolk proteins lost through the renal system or intestine would not be available for growth. These lesions might occur sporadically in pink salmon populations, but because histopathology is not routinely done on either wild or cultured pink salmon, other cases might have been overlooked.

How do ruptured yolk sacs in emergent pink salmon compare to 'coagulated yolk' or 'white spot disease' described in other salmonid species? In other salmon species, yolk material leaking out of the yolk sac sometimes appears as 'small, white, opaque spots or flecks in the normally orange-colored yolk material,' and as fish develop, 'the number of spots of coagulated yolk increase' (Mazuranich \& Nielson 1959, p. 172). Mazuranich \& Nielson (1959) reported a personal communication in which histopathology was done on fish with white spot disease, but they provided no results. Coagulated yolks in chum salmon Oncorhynchus keta caused immediate death of affected fry (Fish \& Burrows 1939). The pink salmon in our study were alive when they were sampled, but postemergent mortality of most of the affected cohorts was greater than in other years. The main difference in pink salmon seems to be the lack of gross signs of disease other than abnormal behavior at emergence; i.e. pink salmon with ruptured yolk sacs lack obvious white spots. The Prince William Sound Aquaculture Corporation rears and releases about 500 million pink salmon fry a year; hatchery personnel do not deem 'coagulated yolk' a problem, but they do not routinely conduct histopathology on their fish (D. Reggiani pers. comm.). Part of the difference between pink salmon and other salmonids might be a result of pink salmon being reared in substrate instead of the open trays common with other salmonid species; by the time pink salmon emerge from the substrate and can easily be examined, their body wall is opaque. However, some cases of ruptured yolk sacs in other salmonids are also not easily diagnosed as coagulated yolk or white spot disease. For example, among diagnostic cases submitted to G.D.M. in 2006 and 2007 from hatcheries in British Columbia and the Yukon Territory, Canada, ruptured yolk sacs with features similar to Alaskan pink salmon affected Chinook salmon $O$. tshawytscha, Atlantic salmon Salmo salar, and bull trout Salvelinus confluentus; in all 3 cases, the submitter noted abnormal clinical signs among the affected fish, but white spots were not noted and coagulated yolk was not suspected. However, submissions from the same clients in 2008 
and 2009 noted white spots and a suspicion of coagulated yolk that was confirmed by histopathology.

Coagulated yolk and white spot disease have traditionally been attributed to trauma during development (Leach 1924, Agersborg 1933), but numerous cases cannot be explained (Boyd 2001). One hypothesis is that poor fish condition contributes to the increased frequency of ruptured yolk sacs. As evidence in our study, not all of the abnormal fish had ruptured yolk sacs or visceral fungi, and this finding is consistent with a previous study (Mazuranich \& Nielson 1959). Therefore, something other than these lesions contributed to the clinical signs. Although bacterial and viral culture were not done on samples in 1999, viral infections probably did not contribute to the clinical signs because pink salmon are resistant to infection with endemic infectious hematopoietic necrosis virus and viral hemorrhagic septicemia virus (Follett et al. 1997). Also, significant bacterial infections would have been detected by histopathology.

When did the yolk sacs rupture? As evidence that the yolk sacs ruptured more than a few hours before sampling, yolk proteins from ruptured yolk sacs were often distributed in several organs, and proteins remaining in the abdominal cavity stained paler than in fish with intact yolks (Fig. 1). As evidence that some yolk sacs ruptured more than a few days before sampling, sections of fish with ruptured yolk sacs sometimes contained few remnants of the yolk sac; presumably, this was a result of resorption after the yolk sacs ruptured. Further, a common method of sampling pre-emergent pink salmon from streams is to pump high-pressure water through the gravel to force the alevins out of the substrate. When yolk sacs rupture under these conditions, affected fish usually have internal hemorrhage (G. Marty unpubl. obs.). By comparison, none of the fish with ruptured yolk sacs in the present study had internal hemorrhage. Pink salmon culture systems are designed to allow volitional emergence (Marty et al. 1997a), so the chance of traumatic yolk sac rupture is minimal for alevins in good condition reared under standard hatchery conditions. Several generations of pink salmon have been cultured using standardized techniques at hatcheries in both regions of Alaska, with no evidence of yolk sac rupture outside of 1994 in Prince William Sound and 1999 at Little Port Walter.

Features of the fungus in emergent pink salmon alevins are consistent with some of the features described for fungal infections of the stomach and swimbladder of other salmonids. Ross et al. (1975) described infections with Phoma herbarum primarily in the swimbladder; attempts to fulfill Koch's postulates met with limited success, but they concluded that $P$. herbarum was a facultative fish pathogen. Ellis et al. (1983) described infections with a hyphomycete that affected serosal surfaces of most tissues in the peritoneal cavity of Atlantic salmon parr; fungal hyphae invaded the swimbladder but did not invade the stomach or proximal intestine. The unidentified septate hyphae described by Miyazaki et al. (1977) also invaded the swimbladder of affected fry. Hyphae of $P$. herbarum were common in the stomach, swimbladder, and surrounding tissues of affected Chinook salmon (Faisal et al. 2007). In all of these accounts, affected fish were never clinically normal.

In conclusion, ruptured yolk sacs and invasive visceral fungi are important lesions associated with decreased marine survival. Confirmation of hypotheses linking microscopic lesions to handling or trauma, poor alevin condition, or some other variable will require controlled laboratory study and more extensive field studies.

Acknowledgements. We thank W. Widmann for histotechnology and N. Willits for statistical analysis; J.B. Olsen sampled the fish in Prince William Sound, D. Reggiani provided mortality and return data for Prince William Sound, and M. Plotnick provided commercial fisheries data from the Alaska Department of Fish and Game. D. Marty reviewed the manuscript. The research described in this paper was supported by the Prince William Sound Aquaculture Corporation and the 'Exxon Valdez' Oil Spill Trustee Council.

\section{LITERATURE CITED}

Agersborg HPK (1933) Salient problems in the artificial rearing of salmonoid fishes, with special reference to intestinal fungisitosis and the cause of white-spot disease. Trans Am Fish Soc 63:240-250

Boyd SR (2001) An evaluation of treatments to reduce mortality from coagulated yolk disease in hatchery-produced Chinook salmon. N Am J Aquaculture 63:246-251

Bue BG, Sharr S, Moffitt SD, Craig AK (1996) Effects of the Exxon Valdez oil spill on pink salmon embryos and preemergent fry. Am Fish Soc Symp 18:619-627

Carls MG, Heintz RA, Marty GD, Rice SD (2005) Cytochrome P4501A induction in oil-exposed pink salmon Oncorhynchus gorbuscha embryos predicts reduced survival potential. Mar Ecol Prog Ser 301:253-265

Cooney RT, Brodeur RD (1998) Carrying capacity and North Pacific salmon production: stock-enhancement implications. Bull Mar Sci 62:443-464

Downton MW, Miller KA (1998) Relationships between Alaskan salmon catch and North Pacific climate on interannual and interdecadal time scales. Can J Fish Aquat Sci 55:2255-2265

Ellis AE, Waddell IF, Minter DW (1983) A systematic fungal disease in Atlantic salmon parr, Salmo salar L., caused by a species of Phialophora. J Fish Dis 6:511-523

Faisal M, Elsayed E, Fitzgerald SD, Silva V, Mendoza L (2007) Outbreaks of phaeohyphomycosis in the Chinook salmon (Oncorhynchus tshawytscha) caused by Phoma herbarum. Mycopathologia 163:41-48

- Fish FF, Burrows RE (1939) Notes of the effect of low temperature upon eyed eggs. Prog Fish Cult 6:28-31

> Follett JE, Meyers TR, Burton TO, Geesin JL (1997) Comparative susceptibilities of salmonid species in Alaska to 
infectious hematopoietic necrosis virus (IHNV) and north American viral hemorrhagic septicemia virus (VHSV). J Aquat Anim Health 9:34-40

- Geiger HJ, Smoker WW, Zhivotovsky LA, Gharrett AJ (1997) Variability of family size and marine survival in pink salmon (Oncorhynchus gorbuscha) has implications for conservation biology and human use. Can J Fish Aquat Sci 54:2684-2690

Heard WR (1991) Life history of pink salmon (Oncorhynchus gorbuscha). In: Groot C, Margolis L (eds) Pacific salmon life histories. University of British Columbia Press, Vancouver, p 119-230

Heintz RA, Rice SD, Wertheimer AC, Bradshaw RF, Thrower FP, Joyce JE, Short JW (2000) Delayed effects on growth and marine survival of pink salmon Oncorhynchus gorbuscha after exposure to crude oil during embryonic development. Mar Ecol Prog Ser 208:205-216

Helle JH, Williamson RS, Bailey JE (1964) Intertidal ecology and life history of pink salmon at Olsen Creek, Prince William Sound, Alaska. Report No. 483, US Fish Wildl Serv, Washington, DC

Jones SRM, Fast MD, Johnson SC, Groman DB (2007) Differential rejection of salmon lice by pink and chum salmon: disease consequences and expression of proinflammatory genes. Dis Aquat Org 75:229-238

Jones S, Kim E, Bennett W (2008) Early development of resistance to the salmon louse, Lepeophtheirus salmonis (Kroyer), in juvenile pink salmon, Oncorhynchus gorbuscha (Walbaum). J Fish Dis 31:591-600

Krkosek M, Lewis MA, Morton A, Frazer LN, Volpe JP (2006) Epizootics of wild fish induced by farm fish. Proc Natl Acad Sci USA 103:15506-15510

Krkosek M, Ford JS, Morton A, Lele S, Myers RA, Lewis MA (2007) Declining wild salmon populations in relation to parasites from farm salmon. Science 318:1772-1775

Leach GC (1924) Artificial propagation of brook trout and rainbow trout, with notes on three other species. Rep US Comm Fish for 1923, Appendix VI, Document 955, US Government Printing Office, Washington, DC

Marty GD (2007) Blank-field correction for achieving a uniform white background in brightfield digital photomicro-

Editorial responsibility: Sven Klimpel,

Düsseldorf, Germany graphs. Biotechniques 42:716-720

Marty GD, Heintz RA, Hinton DE (1997a) Histology and teratology of pink salmon larvae near the time of emergence from gravel substrate in the laboratory. Can J Zool 75: 978-988

- Marty GD, Short JW, Dambach DM, Willits NH and others (1997b) Ascites, premature emergence, increased gonadal cell apoptosis, and cytochrome-P4501A induction in pink salmon larvae continuously exposed to oil-contaminated gravel during development. Can J Zool 75:989-1007

> Mazuranich JJ, Nielson WE (1959) White-spot disease of salmon fry. Prog Fish Cult 21:172-176

Miyazaki T, Kubota SS, Tashiro F (1977) Studies on visceral mycosis of salmonid fry. I. Histopathology. Fish Pathol 11:183-186

> Morita K, Morita SH, Fukuwaka M (2006) Population dynamics of Japanese pink salmon (Oncorhynchus gorbuscha): are recent increases explained by hatchery programs or climatic variations? Can J Fish Aquat Sci 63:55-62

Parker RR (1968) Marine mortality schedules of pink salmon of Bella Coola River, Central British Columbia. J Fish Res Board Can 25:757-794

Ross AJ, Yasutake WT, Leek S (1975) Phoma herbarum, a fungal plant saprophyte as a fish pathogen. J Fish Res Board Can 32:1648-1652

Webster SJ, Dill LM, Butterworth K (2007) The effect of sea lice infestation on the salinity preference and energetic expenditure of juvenile pink salmon (Oncorhynchus gorbuscha). Can J Fish Aquat Sci 64:672-680

Wertheimer AC, Heintz RA, Thedinga JF, Maselko JM, Rice SD (2000) Straying of adult pink salmon from their natal stream following embryonic exposure to weathered Exxon Valdez crude oil. Trans Am Fish Soc 129:989-1004

Wertheimer AC, Thedinga JF, Heintz RA, Bradshaw RF, Celewycz AG (2002) Comparative effects of half-length coded wire tagging and ventral fin removal on survival and size of pink salmon fry. N Am J Aquac 64:150-157

Yazawa R, Yasuike M, Leong J, von Schalburg KR and others (2008) EST and mitochondrial DNA sequences support a distinct Pacific form of salmon louse, Lepeophtheirus salmonis. Mar Biotechnol 10:741-749

Submitted: January 6, 2009; Accepted: September 21, 2009 Proofs received from author(s): December 22, 2009 